\title{
Study of Substituent Effects and Correlations of Molecular Ionization Energies of Some Organic Compounds
}

\author{
Muayed Khaleel Ibrahim \\ Baghdad University, College of Science, Chemical Department, Iraq,Baghdad ,al-jadria
}

\begin{abstract}
Ionizing energies of the gas phase of various organic compound such Amines, alcohol, ethers, thiol, aldehydes, ketones, carboxylic acids and esters. Has been measured to explore any arrangements and linkages within each group and any possible reciprocal links between groups of similar compounds. It has been found that there is a common pattern of mutual relations and correlations regardless of the type of functional group, and that ionizing energies within similar groups are interrelated depending on the number of carbon atoms and alkyl groups involved. The identification of these interlinkages and linkages has helped to exactly estimate of ionizing energies of different sets of analogue compound.
\end{abstract}

Keywords: Ionizationenergy; Grouplink between functional groups; Functionai groups of oraganic compound

\section{Introduction}

There were many attempts at finding empirical or semi-empirical relationships to calculate molecular ionization energies but as yet there is no simple method for accurate estimation of this important property(1-6)and Many attempts for representative atomic and molecular systems $(7,8)$.the ionization energies of alkanes, alkenes, alkynes and alkyl benzeneswere found to correlate with the number of carbon atoms of the alkyl chain for normal moleculesor to the number of methyl groups in the case of branched molecules(9). These results have also shown that as the number of carbon atoms (n) in the chain of n-alkanesincreases the molecules become less amenable to ionizationand what may be called a "molecular shielding effect" becomes effective for $(n>5)$. Such behavior made it difficult to obtain accurate ionization-energy values for large alkanes.

\section{Experimental Work}

In the present paper the same procedure was followed as (9).That is to recognize through multi regression analysis patterns of behavior of molecular ionization energies in order to arrive at such correlations and cross-correlations as may assist in the estimation of new ionization-energy values, or of more accurate ones than are available now. For this purpose the derivatives examined were arranged in analogous sets each represented by the general formula $\mathrm{RmXHv}-\mathrm{m}$ where (m) is the number of alkyl groups $\mathrm{R}$ attached to the functional group $\mathrm{X}$ and (v) is the maximum number of groups or atoms that can be attached to it. $\mathrm{X}$ may have any of the designations listed below according to the type of"functional" group involved viz.:

a) The amines RmNHv-m ( $v=3, m=0,1,2,3)$

b) The alcohols and ethers RmOHv-m ( $v=2, m=0,1,2)$

c) The thiols and thioethersRmSHv-m $(v=2, m=0,1,2)$

d) The aldehydes and ketones $\mathrm{RmC}(0) \mathrm{Hv}-\mathrm{m}(\mathrm{v}=2, \mathrm{~m}=0,1,2)$

e) The carboxylic acids and esters $\mathrm{R} C(0) 0 \mathrm{Hv}-\mathrm{mRm}$ $(\mathrm{v}=1, \mathrm{~m}=0,1)$

Within each such analogous sets all possible correlations andcross-correlations were examined with special attention being paid to the influence of the type (i.e. length) and number of alkyl groups.

The values of ionization energies used were those available in the literature(10-12) again trying to work with values from the same source and determined by the same methods; paying special attention to whether the methods give vertical or adiabatic ionization energies. Also, in trying to avoid the difficulty of using any systemof units.All ionization energies for the members of any set of "functional" group were normalized to that of a standard molecule of the set which was given the values 100.e.g; in the case of the amines. Their ionization-energy values were normalized to that of $\mathrm{NH}_{3}$.for which the value of $10.15 \mathrm{eV}$ was taken as determined by Watanabe and coworkers(11) using photoionization method. Thus as in Part I. all calculations were carried out using these relative ionization energy values (Er). Conversion to values in any system of units becomes then an easy procedure.

\section{Result and Discussion}

\section{a) Alky1 Amines}

The alkyl amines all follow rather nicely three mainlinear functions representing monoalkyl, dialkyl and trialkyl amines, and for any given alkyl group the three amines fall on a straight line which is nearly parallel to that for the other alkyl groups as shown in (Figure 1). The straight line for $\left(\mathrm{CH}_{3}\right)$ mNHv-m (see line 4 in Figure 1) passes also through the point for NH3. Table lgives the "best" functions with the highest coefficients of correlations. These functions were used to calculate rather accurate ionization-energy values for a number of amines with alkyl groups up to $(n=5)$.for the higher alkyl groups there may be greater inaccuracy in the estimated values due to the "molecular shielding effect" observed for long chain alkanes with $(n>5)$ as discussed in (9). Table 2 lists the values thus obtained.

The regular pattern obtained for the amines with its correlations and cross-correlations with remarkably high coefficients of correlation $(>0.99$ ) shows quite clearly the

\section{Volume 6 Issue 12, December 2017}




\section{International Journal of Science and Research (IJSR) \\ ISSN (Online): 2319-7064 \\ Index Copernicus Value (2016): 79.57 | Impact Factor (2015): 6.391}

monotonous effect of successive alkyl substitutions. Judging from the values of the slopes (for lines 1, 2 and 3 of Figure 1) which increased in the orders:

Monoalkylamine $<$ dialkylamines $<$ trialkylamines and the almost constant slopes for the lines linking any three of the amines belonging to the same alkyl group, the following conclusion may be made:

1) The more alkyl groups are substituted and the longer the alkyl chain the greater is the reduction in the ionization energy of the amine.

2) The introduction of the first alkyl group influences the ionization energy to a larger extent than that of the Second group and that in turn is more than for the third group.

3) This decrement upon the successive introduction of alkyl groups indicates the operation of saturation forces on the ease of ionization of the amine group.

Table 1: The functions with "best" coefficients of correlation for the relative values of ionization energies (Er)*for amines as functions of the number of carbon atoms $(n)$ in the $n$-alkyl chain. The general equation is: $\operatorname{In} \operatorname{Er}=a+b \operatorname{In}(n+1)$

\begin{tabular}{|c|c|c|c|c|c|c|}
\hline $\begin{array}{c}* * \\
\text { Line No. }\end{array}$ & The set of & $\mathrm{a}$ & $\mathrm{b}$ & $\begin{array}{c}\text { Coefficientof } \\
\text { correlation }\end{array}$ & $\begin{array}{c}\text { Standard deviation } \\
\text { of slope }\end{array}$ & $\begin{array}{c}\text { Standard deviation of } \\
\text { intercept }\end{array}$ \\
\hline $\mathbf{1}$ & monoalkyl amines & 4.499 & -0.032 & 0.9970 & $0.780 \mathrm{E}-03$ & $2.446 \mathrm{E}-02$ \\
\hline $\mathbf{2}$ & dialkyl amines & 4.462 & -0.062 & 0.9998 & $3.122 \mathrm{E}-03$ & $5.015 \mathrm{E}-02$ \\
\hline $\mathbf{3}$ & trialkyl amines & 4.458 & -0.085 & 0.9971 & $7.599 \mathrm{E}-03$ & $8.977 \mathrm{E}-02$ \\
\hline $\mathbf{4}$ & $\mathrm{NH}_{3}$, methyl amines & 4.607 & -0.193 & 0.9996 & $3.378 \mathrm{E}-03$ & $1.751 \mathrm{E}-02$ \\
\hline $\mathbf{5}$ & ethyl amines & 4.680 & -0.197 & $\sim 1.000$ & $0.522 \mathrm{E}-03$ & O.027E-02 \\
\hline $\mathbf{6}$ & propyl amines & 4.749 & -0.211 & 0.9995 & $6.684 \mathrm{E}-03$ & $3.166 \mathrm{E}-02$ \\
\hline $\mathbf{7}$ & n-butylamines*** & 4.788 & -0.212 & - & - & - \\
\hline
\end{tabular}

* Using Watanabe etal(11)experimental values and taking the value of $10.15 \mathrm{eV}$ for the ionization energy of $\mathrm{NH}_{3}$ to which the values of allamines were normalized.

**The numbers refer to Figure 1.

****obtained from two points only.

Table 2: Estimated values of ionization energies (Ei) of amines by using the equations in Table 1

\begin{tabular}{|c|c|c|}
\hline Molecule & Equation no. & $\begin{array}{c}\text { Estimated values of * } \\
\text { ionization energies }(\mathrm{E} \pm) .(\mathrm{eV})\end{array}$ \\
\hline$\left(\mathrm{n}-\mathrm{C}_{4} \mathrm{H}_{9}\right) 3 \mathrm{~N}$ & 73 & $7.10 \pm 0.01$ (average) \\
\hline $\mathrm{n}-\mathrm{C}_{5} \mathrm{H}_{11} \mathrm{NH}_{2}$ & 1 & 8.66 \\
\hline$\left(\mathrm{n}-\mathrm{C}_{5} \mathrm{H}_{11}\right) 2 \mathrm{NH}$ & 2 & 7.63 \\
\hline$\left(\mathrm{n}-\mathrm{C}_{5} \mathrm{H}_{11}\right) 3 \mathrm{~N}$ & 3 & 6.96 \\
\hline
\end{tabular}

* Ei values were calculated based on Watanabe et al value for $\mathrm{NH}_{3}$ of $10.15 \mathrm{eV}$ (11).

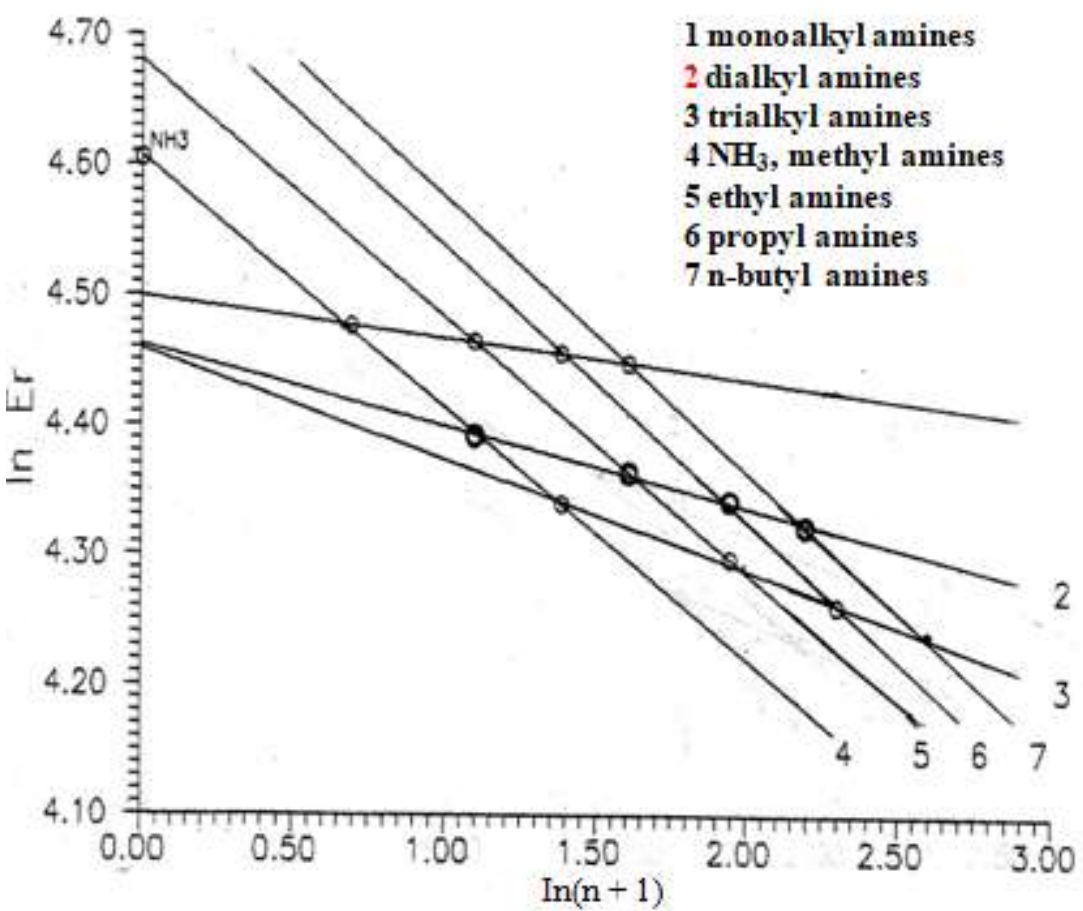

Figure1: The logarithmic functions with best coefficients of correlation of relative ionization energies

(Er) and no. of carbon atoms (n) for alky1.dialky1 and trialky1 amines.

Er-values were referred to the ionization energy of $\mathrm{NH}_{3}$ taken as $10.15 \mathrm{ev}$ (11).

Volume 6 Issue 12, December 2017

www.ijsr.net

Licensed Under Creative Commons Attribution CC BY 


\section{International Journal of Science and Research (IJSR) \\ ISSN (Online): 2319-7064 \\ Index Copernicus Value (2016): 79.57 | Impact Factor (2015): 6.391}

\section{1- Alcohols and Ethers}

When the sets of alcohols and ethers of the general formula RmOHv-m were examined.as shown in (Figure 2).Similarbehavior to that for alkyl amines was observed. Table 3 gives the "best" functions with highest coefficients ofcorrelation, and the estimated values for alkanols and their corresponding ethers up to $n=5$ are given in Table 4 . The corresponding thio-compounds were also found to follow similar pattern as can be seen from (Figure 3) and Table 3.With the exception of the deviation of the trio $\mathrm{H}_{2} \mathrm{~S}, \mathrm{CH}_{3} \mathrm{SH}$ and $\mathrm{CH}_{3} \mathrm{SCH}$ from linearity. However, the lines connecting the pairs of thiols and thioethers for alkyl groups with $n=1,2$ and 3 are almost nearly parallel in harmony with the corresponding oxy compounds.

It is interesting to note that the ionization energy function of ethyl methyl sulphide occupies an intermediate position between that of dimethyl sulphide and diethyl sulphide. This observation if applied to the other sets may help in estimating ionization energy values for mixed ethers and possibly also for amines. Table 4 gives some estimated values for the ionization energies of some oxy and thio compounds keeping in mind that those for higher alkyls with $n>5$ would be expected to be of lesser accuracy.

Table 3: The functions with "best" coefficients of correlation for the relative values of ionization energies (Er)*for alcohols, ethers, thiols and thioethers as functions of the number of carbon atoms (n) in the $n$-alky1 chain. The general equation is: InEr=

\begin{tabular}{|c|c|c|c|c|c|c|}
\hline $\begin{array}{c}* * \\
\text { Line no. }\end{array}$ & The set of & $\mathrm{a}$ & $\mathrm{b}$ & $\begin{array}{c}\text { Coefficient of } \\
\text { corre1ation }\end{array}$ & $\begin{array}{c}\text { Standarddeviat } \\
\text { ionof slope }\end{array}$ & $\begin{array}{c}\text { Standarddeviatio } \\
\mathrm{n} \text { ofintercept }\end{array}$ \\
\hline 1 & alkanols & 4.516 & $-8.58 \mathrm{E}-02$ & 0.9994 & $2.534 \mathrm{E}-03$ & $2.952 \mathrm{E}-02$ \\
\hline 2 & Dialky1 ethers & 4.473 & $-8.99 \mathrm{E}-02$ & $\sim 1.00$ & $3.279 \mathrm{E}-03$ & $3.649 \mathrm{E}-02$ \\
\hline 3 & $\mathrm{H}_{2} \mathrm{O}, \mathrm{CH}_{3} \mathrm{OH},\left(\mathrm{CH}_{3}\right) 20$ & 4.604 & $-21.0 \mathrm{E}-02$ & 0.9998 & $3.518 \mathrm{E}-03$ & $1.673 \mathrm{E}-02$ \\
\hline 4 & $\mathrm{C}_{2} \mathrm{H}_{5} \mathrm{OH},\left(\mathrm{C}_{2} \mathrm{H}_{5}\right) 20^{* * *}$ & 4.626 & $-18.6 \mathrm{E}-02$ & - & - & - \\
\hline 5 & $\mathrm{C}_{3} \mathrm{H}_{7} \mathrm{OH},\left(\mathrm{C}_{3} \mathrm{H}_{7}\right) 20^{* * *}$ & 4.631 & $-17.1 \mathrm{E}-02$ & - & - & - \\
\hline $1^{\prime}$ & Alky1thiols & 4.526 & $-3.55 \mathrm{E}-02$ & 0.9914 & $2.142 \mathrm{E}-03$ & $6.029 \mathrm{E}-02$ \\
\hline $2^{\prime}$ & dialky1 thioethers & 4.478 & $-5.41 \mathrm{E}-02$ & $\sim 1.00$ & $1.348 \mathrm{E}-03$ & $2.493 \mathrm{E}-02$ \\
\hline $3^{\prime}$ & $\mathrm{CH}_{3} \mathrm{SH},\left(\mathrm{CH}_{3}\right) 2 \mathrm{~S}^{* * *}$ & 4.645 & $-20.6 \mathrm{E}-02$ & - & - & - \\
\hline $4^{\prime}$ & $\mathrm{C}_{2} \mathrm{H}_{5} \mathrm{SH},\left(\mathrm{C}_{2} \mathrm{H} 5\right) 2 \mathrm{~S}^{*} * *$ & 4.694 & $-18.9 \mathrm{E}-02$ & - & - & - \\
\hline $5^{\prime}$ & $\mathrm{C}_{3} \mathrm{H}_{7} \mathrm{SH},\left(\mathrm{C}_{3} \mathrm{H}_{7}\right) 2 \mathrm{~S}^{* * *}$ & 4.729 & $-18.3 \mathrm{E}-02$ & - & - & - \\
\hline
\end{tabular}

* Using Watanabe etal (11) experimental values and taking for the oxy compounds water as standard with the value of $10.59 \mathrm{eV}$ and for thio compounds $\mathrm{H}_{2} \mathrm{~S}$ with the value of $10.46 \mathrm{eV}$ to which all oxy and thio compounds were referred, respectively.

**The numbers refer to Figures 2 and 3.

*** Obtained from two points only.

Tab1e 4: Estimated values of ionization energies(Er)of oxy and thioa $1 \mathrm{k} \mathrm{y} 1 \mathrm{~s}$ by using the equations in Table 3.

\begin{tabular}{|c|c|c|}
\hline Molecule & Equation no. & $\begin{array}{c}\text { Estimated values of * } \\
\text { ionization energies (Ei). (eV) }\end{array}$ \\
\hline$\left(\mathrm{n}-\mathrm{C}_{4} \mathrm{H}_{9}\right) 20$ & 2 & 9.05 \\
\hline $\mathrm{n}-\mathrm{C}_{5} \mathrm{H}_{11} \mathrm{OH}$ & 1 & 9.88 \\
\hline$\left(\mathrm{n}-\mathrm{C}_{5} \mathrm{H}_{11}\right) 20$ & 2 & 8.89 \\
\hline$\left(\mathrm{n}-\mathrm{C}_{4} \mathrm{H}_{9}\right) 2 \mathrm{~S}$ & $2^{\prime}$ & 8.18 \\
\hline $\mathrm{n}-\mathrm{C}_{5} \mathrm{H}_{11} \mathrm{SH}$ & $1^{\prime}$ & 9.07 \\
\hline$\left(\mathrm{n}-\mathrm{C}_{5} \mathrm{H}_{11}\right) 2 \mathrm{~S}$ & $2^{\prime}$ & 8.09 \\
\hline
\end{tabular}

*Ei values for oxy and thio compounds were calculated based on watanabeetal values for $\mathrm{H}_{2} \mathrm{O}$ and $\mathrm{H}_{2} \mathrm{~S}$ of 10.59 and $10.46 \mathrm{eV}$ respectively (11). 
International Journal of Science and Research (IJSR)

ISSN (Online): 2319-7064

Index Copernicus Value (2016): 79.57 | Impact Factor (2015): 6.391

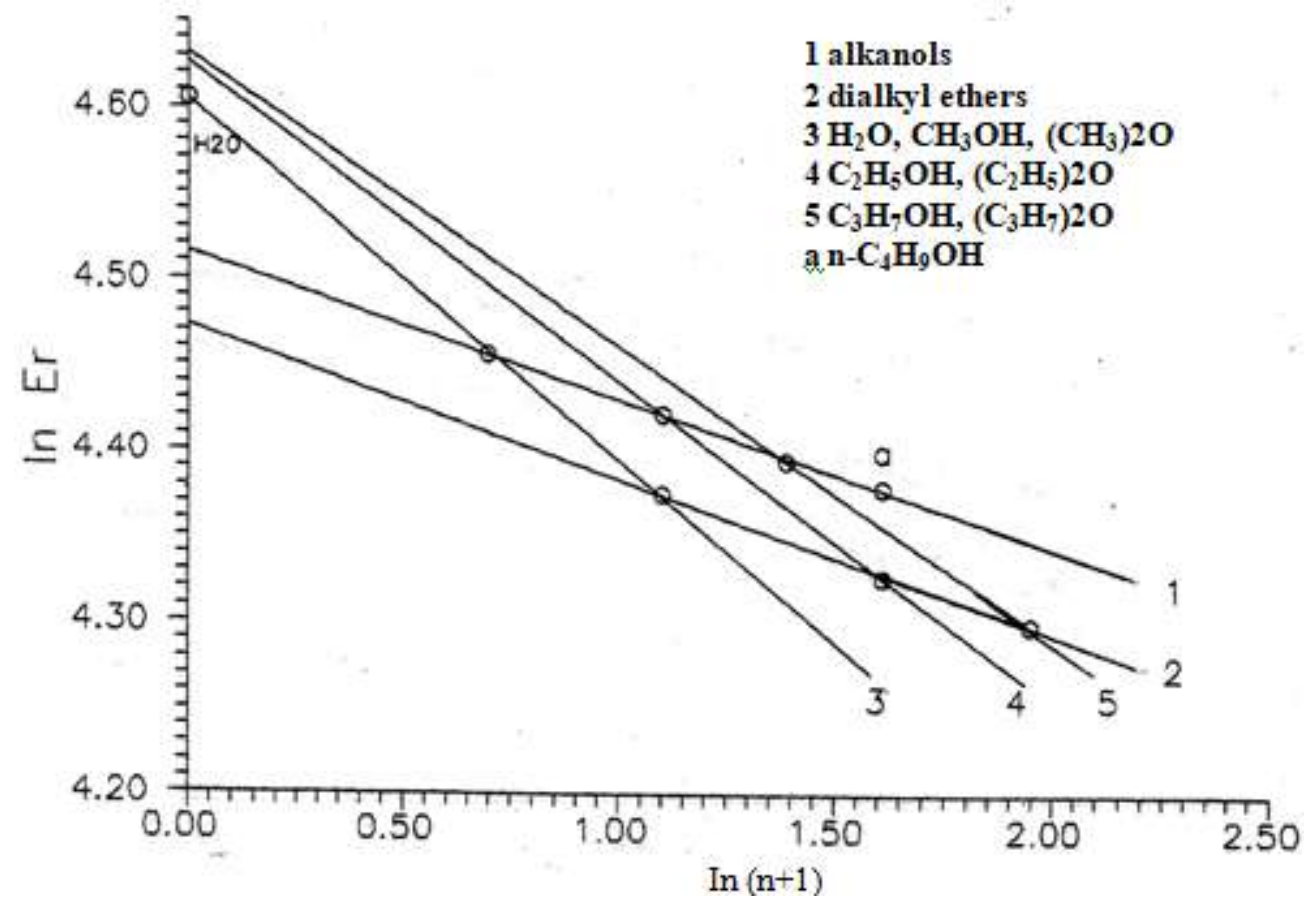

Figure 2: The logarithmic functions with best coefficients of correlation of relative ionization energies (Er) and no. of carbon atoms (n) for alkanols and ethers.

Er-values were referred to the ionization energy of $\mathrm{H}_{2} \mathrm{O}$ taken as $12.59 \mathrm{eV}(11)$.

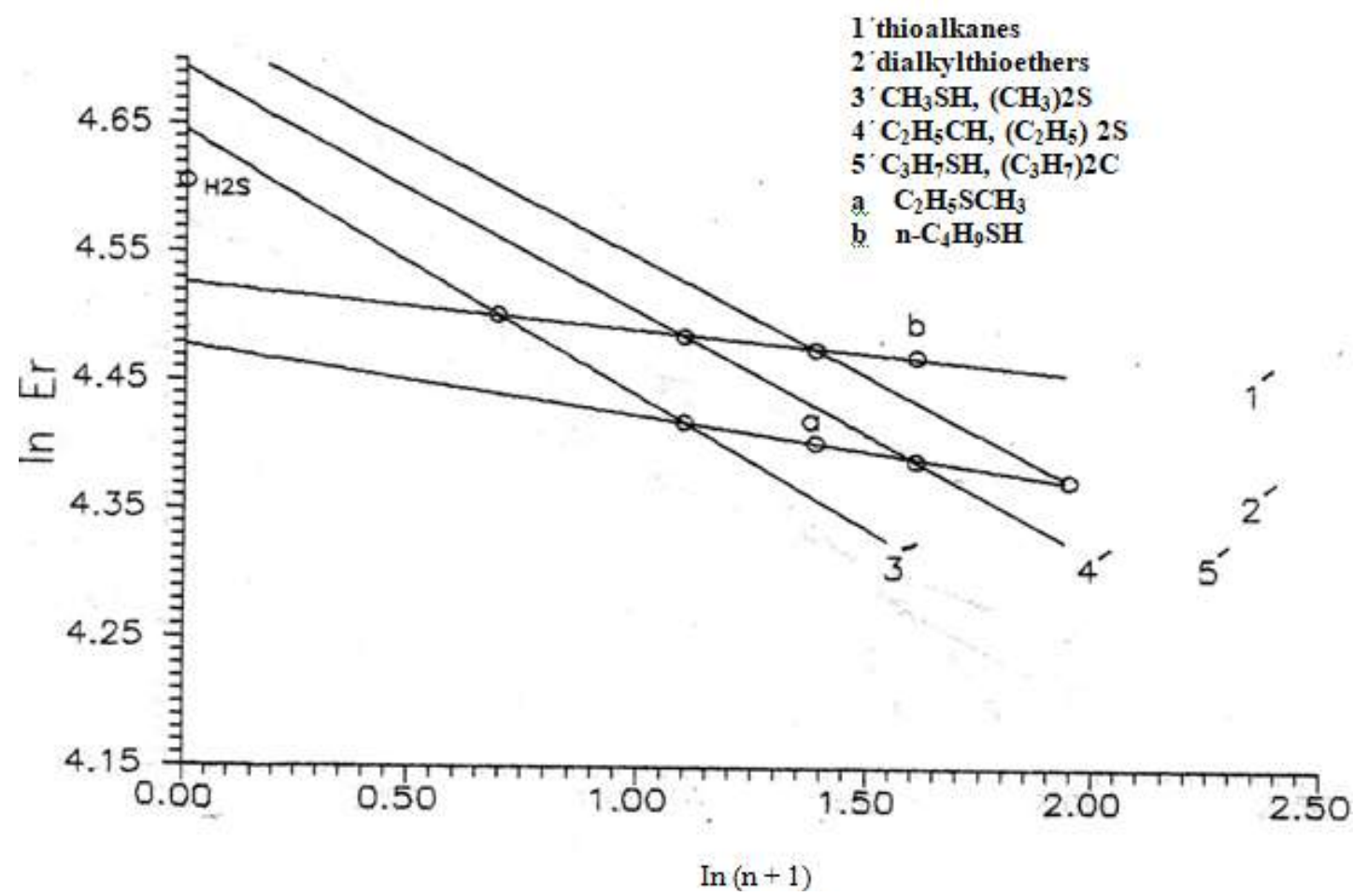

Figure 3: The logarithmic functions with best coefficients of correlation of relative ionization energies (Er) and no. of carbon atoms ( $\mathrm{n}$ ) for thioalkanes and dialkylthioethers.

Er-values were referred to the ionization energy of $\mathrm{H}_{2} \mathrm{~S}$ taken as $10.46 \mathrm{eV}(11)$

\section{2-Aldehydes and Ketones}

In spite of the scarcity of data for the dialky1 ketones, the sets of aldehydes and ketones would be expected to follow similar pattern to that for the alcohols and ethers and their corresponding thio compounds, and (Figure 4) and Table 5 were constructed accordingly. Here the trio $\mathrm{HCHO}, \mathrm{CH}_{3} \mathrm{CHO}$ and $\left(\mathrm{CH}_{3}\right)_{2} \mathrm{CO}$ deviated from linearity. But the lines connecting the pairs of aldehyde and ketone of the same alkyl group are very nearly parallel as for the previous sets. Table 6 gives some estimated values of ionization energies of aldehydes and ketones with alkyl groups up to $n=5$.

The interesting case to note here is that of the mixed methyl alkyl ketones which fall on a straight line of their own as can be seen from (Figure 4).

Volume 6 Issue 12, December 2017

\author{
www.ijsr.net
}

Licensed Under Creative Commons Attribution CC BY 


\section{International Journal of Science and Research (IJSR) \\ ISSN (Online): 2319-7064}

Index Copernicus Value (2016): 79.57 | Impact Factor (2015): 6.391

Table 5: The functions with "best" coefficients of correlation for the relative values of ionization energies (Er)*for aldehydes and ketones as functions of the number of carbon atoms (n) in the $n$-alkyl chain. The general equation is: $\operatorname{In} \mathrm{Er}=\mathrm{a}+\mathrm{b} \ln (\mathrm{n}+1)$

\begin{tabular}{|c|c|c|c|c|c|c|}
\hline $\begin{array}{c}* * \\
\text { Line } \\
\text { no. }\end{array}$ & The set of & $\mathrm{a}$ & $\mathrm{b}$ & $\begin{array}{c}\text { Coefficient } \\
\text { of } \\
\text { correlation }\end{array}$ & $\begin{array}{c}\text { Standard } \\
\text { deviation of } \\
\text { slope }\end{array}$ & $\begin{array}{c}\text { Standard } \\
\text { deviation of } \\
\text { intercept }\end{array}$ \\
\hline 1 & aldehydes & 4.570 & $-4.62 \mathrm{E}-02$ & 0.9777 & $5.614 \mathrm{E}-03$ & $12.896 \mathrm{E}-02$ \\
\hline 2 & Dialky1 ketones*** & 4.574 & $-7.62 \mathrm{E}-02$ & - & - & - \\
\hline 3 & Methy1 ketones & 4.550 & $-5.49 \mathrm{E}-02$ & 0.9894 & $4.670 \mathrm{E}-03$ & $8.511 \mathrm{E}-02$ \\
\hline 4 & $\mathrm{CH}_{3} \mathrm{CHO}_{2}\left(\mathrm{CH}_{3}\right) 2 \mathrm{CO} * * *$ & 4.632. & $-12.9 \mathrm{E}-02$ & - & - & - \\
\hline 5 & $\mathrm{C}_{2} \mathrm{H}_{5} \mathrm{CHO}_{2}\left(\mathrm{C}_{2} \mathrm{H}_{5}\right) 2 \mathrm{CO} * * *$ & 4.667 & $-13.4 \mathrm{E}-02$ & - & - & - \\
\hline
\end{tabular}

* Using Watanabeetal(11) experimental values, and taking fomaldehyde asreference compound with the value of $10.87 \mathrm{eV}$ to which the values of all other aldehydes and ketones were normalized.

**The numbers refer to Figures 4.

*** Obtained from two points only

Table 6: Estimated values of ionization energies (Ei) of some aldehydes and ketones by using the equations in Table 5

\begin{tabular}{|c|c|c|}
\hline Molecule & $\begin{array}{c}\text { Equation } \\
\text { no. }\end{array}$ & $\begin{array}{c}\text { Estimated values of } \\
* \text { ionization energies } \\
(\text { Ei). }(\mathrm{eV})\end{array}$ \\
\hline $\mathrm{n}-\mathrm{C}_{5} \mathrm{H}_{11} \mathrm{CHO}$ & 1 & 9.71 \\
\hline$\left(\mathrm{C}_{3} \mathrm{H}_{7}\right) 2 \mathrm{CO}$ & 3 & 9.24 \\
\hline$\left(\mathrm{n}-\mathrm{C}_{4} \mathrm{H}_{9}\right) 2 \mathrm{CO}$ & 3 & 9.12 \\
\hline$\left(\mathrm{n}-\mathrm{C}_{5} \mathrm{H}_{11}\right) 2 \mathrm{CO}$ & 3 & 9.02 \\
\hline $\mathrm{n}-\mathrm{C}_{5} \mathrm{H}_{11} \mathrm{COCH}$ & 2 & 9.08 \\
\hline
\end{tabular}

*Ei values were calculated based on Watanabe etal value for formaldehyde of $10.87 \mathrm{eV}(11)$.

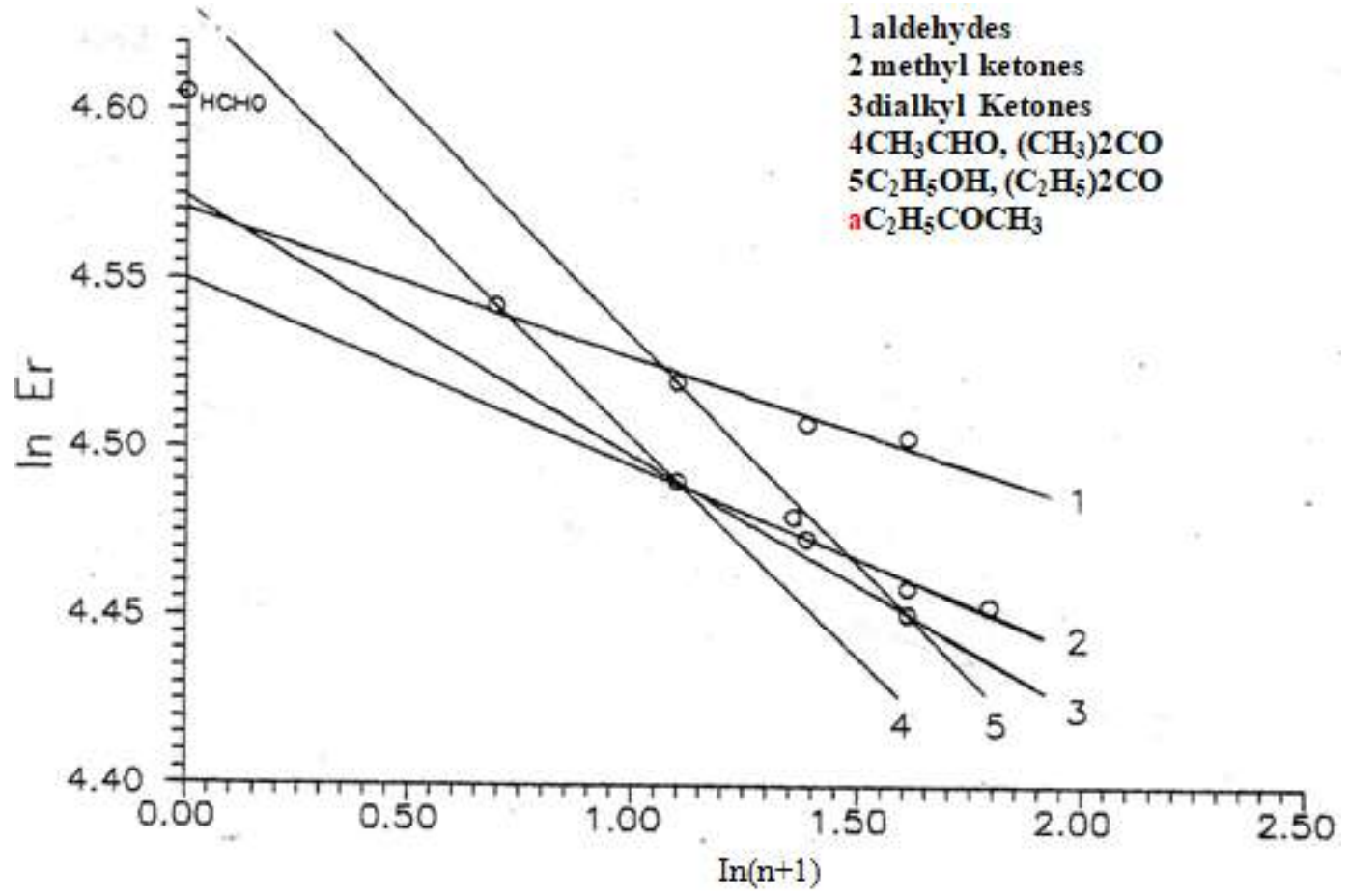

Figure 4: The logarithmic functions with best coefficients of correlation of relativeionization energies (Er) and no. of carbon atoms (n) for aldehydes, dialkyl ketones and methyl ketones.

Er-values were referred to the ionization energy of $\mathrm{HCHO}$ takenas $10.87 \mathrm{eV}(11)$

\section{3-Carboxylic Acids and Esters}

With the exception of the formats and formic acid which behaved uniquely.The ionization energies of all other carboxylic acids seem to fall on a common straight line when the data were handled in the same way as for the previous sets, as can be seen from (Figure 5) and Table 7. But when these compounds were treated in view of the fact that the alkyl group of the ester is constitutionally different from that of the parent carboxylic acid, different functions were then constructed in the forms:

In $E r=a+b \ln (n+j)$

with $\mathrm{j}$ representing the number of carbon atoms in

Volume 6 Issue 12, December 2017 www.ijsr.net

Licensed Under Creative Commons Attribution CC BY 
International Journal of Science and Research (IJSR)

ISSN (Online): 2319-7064

Index Copernicus Value (2016): 79.57 | Impact Factor (2015): 6.391

thecarboxylic acid, i.e., $\mathrm{j}=\mathrm{i}, 2,3, \ldots \ldots$, for formic, acetic, propionic acid, etc., and $\mathrm{n}$ representing the number of carbon atoms in the alkyl groups of the ester with $\mathrm{n}=1,2,3, .$, and referring the ionization energies of a given set of esters to that of their corresponding carboxylic acid, i.e., all acetates were referred to acetic acid and so on. The results so obtained are given in Table 8 and illustrated in (Figure 6 ) from which it can be seen that each acid with its esters fall on a distinct straight line and that these lines seem to be almost parallel. This observation may be used in the estimation of ionization-energy values for some esters. Those for carboxylic acids with greater uncertainty may be obtained from the straight line function obtained for the acids and given in Table7.Table 9 contains all values for acids and their esters estimated in this manner.

In the case of propionic acid and its esters where the experimental points seem to scatter widely about a straight line, it was decided to assume that propionic acid and its esters would fall on a line parallel to those for formic and acetic acids and their esters and to estimate the values for methyl and ethyl propionates; as given in Table 9 where the value for ethyl propionate is estimated at $10.06 \mathrm{eV}$ which falls outside the experimental error given by Watanabe and coworkers who reported the value of $(10.00+0.02) \mathrm{eV}$ for this compound. However, the estimated value for methyl propionate agrees rather well with the experimental value of $10.14 \mathrm{eV}(11)$.

Table 7: The functions with "best" coefficients of correlation for the relative values of ionization energies(Er)* for formic acid, formates and carboxylic acids as functions of the number of carbon atoms (n) in the n-alkyl chain. The general equation is: In Er $=a+b \ln (n+1)$

\begin{tabular}{|c|c|c|c|c|c|c|}
\hline $\begin{array}{c}* * \\
\text { Line no. }\end{array}$ & The set of & $\mathrm{a}$ & $\mathrm{b}$ & $\begin{array}{c}\text { Coefficient of } \\
\text { correlation }\end{array}$ & $\begin{array}{c}\text { Standard } \\
\text { deviation of } \\
\text { slope }\end{array}$ & $\begin{array}{c}\text { Standard deviation } \\
\text { of intercept }\end{array}$ \\
\hline 1 & formic and formates & 4.605 & $-3.318 \mathrm{E}-02$ & 0.9959 & $2.230 \mathrm{E}-03$ & $7.023 \mathrm{E}-02$ \\
\hline 2 & carboxylic acids & 4.562 & $-2.962 \mathrm{E}-02$ & $\sim 1.00$ & $1.069 \mathrm{E}-03$ & $3.612 \mathrm{E}-02$ \\
\hline
\end{tabular}

* Using Watanabe etal(8)experimental values, and taking the values of $11.05 \mathrm{eV}$ for ionization energies of formic acid to which the values of all formates and carboxylic acids were normalized.

$* *$ The numbers refer to Figure 5.

Table 8: The functions with "best" coefficients of correlation for the relative values of ionization energies (Er)* for formates, propionates and n-butionates as functions of the number of carbon atoms (n) in the $n$-alkyl chain. The general equation is: In Er

\begin{tabular}{|c|c|c|c|c|c|c|c|}
\hline $\begin{array}{c}* * \\
\text { Line no. }\end{array}$ & The set of & $\mathrm{j}$ & $\mathrm{a}$ & $\mathrm{b}$ & $\begin{array}{c}\text { Coefficient } \\
\text { of } \\
\text { correlation }\end{array}$ & $\begin{array}{c}\text { Standard } \\
\text { deviation of } \\
\text { slope }\end{array}$ & $\begin{array}{c}\text { Standard } \\
\text { Deviation of } \\
\text { intercept }\end{array}$ \\
\hline $1^{\prime}$ & formic acid ***and formates & 1 & 4.605 & $-3.318 \mathrm{E}-02$ & 0.9959 & $2.230 \mathrm{E}-03$ & $7.023 \mathrm{E}-02$ \\
\hline $2^{\prime}$ & acetic acid and acetates & 2 & 4.630 & $-3.454 \mathrm{E}-02$ & 0.9861 & $3.223 \mathrm{E}-03$ & $9.331 \mathrm{E}-02$ \\
\hline $3^{\prime}$ & Propionic**** acid and propionates & 3 & 4.642 & $-3.386 \mathrm{E}-02$ & - & - & - \\
\hline $4^{\prime}$ & n-buteric****acid and n-buterates & 4 & 4.652 & $-3.386 \mathrm{E}-02$ & - & - & - \\
\hline
\end{tabular}

*Using Watanabe etal(11) experimental values, and taking the value of ionization energy (Ex) of the parent molecule for each set. $\mathrm{Ei}-\mathrm{HCOOH}=11.05 \mathrm{eV} . \mathrm{Ei}-\mathrm{CH}_{3} \mathrm{COOH}=10.37 \mathrm{eV} . \mathrm{Ei}-\mathrm{C}_{2} \mathrm{H}_{5} \mathrm{COOH}=10.24 \mathrm{eV}$. Ei- $\mathrm{C}_{3} \mathrm{H}_{7} \mathrm{COOH}=10.16 \mathrm{eV}$ to which the values of each set were normalized.

**T h e numbers refer to Figure 6.

*** The equation in this set is the same as the corresponding equation in Table 7 and is included here for the sake of comparison. $* * * *$ Equations 3 and 4 were derived using the values of the coordinates for the relative ionization energies of the acids and their respective $\operatorname{In}(\mathrm{n}+\mathrm{j})$ values, and assuming the slope to be that of the average for equations 1 and 2 .

Table 9: Estimated values of ionization energies (Ei) of somecarboxylic acids and esters by using the equations in Table 7 and 8

\begin{tabular}{|c|c|c|}
\hline Molecule & $\begin{array}{c}\text { Equation } \\
\text { no. }\end{array}$ & $\begin{array}{c}\text { Estimated values of* } \\
\text { ionization energies } \\
(\mathrm{Ei}) .(\mathrm{eV})\end{array}$ \\
\hline $\mathrm{HCOO}\left(\mathrm{n}-\mathrm{C}_{5} \mathrm{H}_{11}\right)$ & $1^{\prime}$ & 10.41 \\
\hline $\mathrm{CH}_{3} \mathrm{COO}\left(\mathrm{n}-\mathrm{C}_{5} \mathrm{H}_{11}\right)$ & $2^{\prime}$ & 9.94 \\
\hline $\mathrm{C}_{2} \mathrm{H}_{5} \mathrm{CGOCH}{ }^{*} *$ & $3^{\prime}$ & $10.14(10.15 \pm 0.03)$ \\
\hline $\mathrm{C}_{2} \mathrm{H}_{5} \mathrm{COOC}{ }_{2} \mathrm{H}_{5} * *$ & $3^{\prime}$ & $10.06(10.08 \pm 0.02)$ \\
\hline $\mathrm{C}_{2} \mathrm{H}_{5} \mathrm{COOC}{ }_{3} \mathrm{H}_{7}$ & $3^{\prime}$ & 10.00 \\
\hline $\mathrm{C}_{2} \mathrm{H}_{5} \mathrm{COO}\left(n-\mathrm{C}_{4} \mathrm{H}_{9}\right)$ & $3^{\prime}$ & 9.95 \\
\hline $\mathrm{C}_{2} \mathrm{H}_{5} \mathrm{COO}\left(n-\mathrm{C}_{5} \mathrm{H}_{11}\right)$ & $3^{\prime}$ & 9.90 \\
\hline $\mathrm{C}_{3} \mathrm{H}_{7} \mathrm{COOCH}$ & $4^{\prime}$ & 10.08 \\
\hline $\mathrm{C}_{3} \mathrm{H}_{7} \mathrm{COOC} \mathrm{H}_{5}$ & $4^{\prime}$ & 10.02 \\
\hline
\end{tabular}

Volume 6 Issue 12, December 2017 www.ijsr.net

Licensed Under Creative Commons Attribution CC BY 
International Journal of Science and Research (IJSR)

ISSN (Online): 2319-7064

Index Copernicus Value (2016): 79.57 | Impact Factor (2015): 6.391

\begin{tabular}{|c|c|c|}
\hline $\mathrm{C}_{3} \mathrm{H}_{7} \mathrm{COOC} \mathrm{H}_{7}$ & $4^{\prime}$ & 9.97 \\
\hline $\mathrm{C}_{3} \mathrm{H}_{7} \mathrm{COO}\left(\mathrm{n}-\mathrm{C}_{4} \mathrm{H}_{9}\right)$ & $4^{\prime}$ & 9.92 \\
\hline $\mathrm{C}_{3} \mathrm{H}_{7} \mathrm{COO}\left(\mathrm{n}-\mathrm{C}_{5} \mathrm{H}_{11}\right)$ & $4^{\prime}$ & 9.88 \\
\hline $\mathrm{n}-\mathrm{C}_{4} \mathrm{H}_{9} \mathrm{COOH}$ & 2 & 10.09 \\
\hline $\mathrm{n}-\mathrm{C}_{5} \mathrm{H}_{11} \mathrm{COOH}$ & 2 & 10.04 \\
\hline
\end{tabular}

* Ei values were calculated based on Watanabe etal values of the parent molecules for each set (see foot-note in Table 8).

** Values in paratheses are experimental values of Watanabe etal(8).

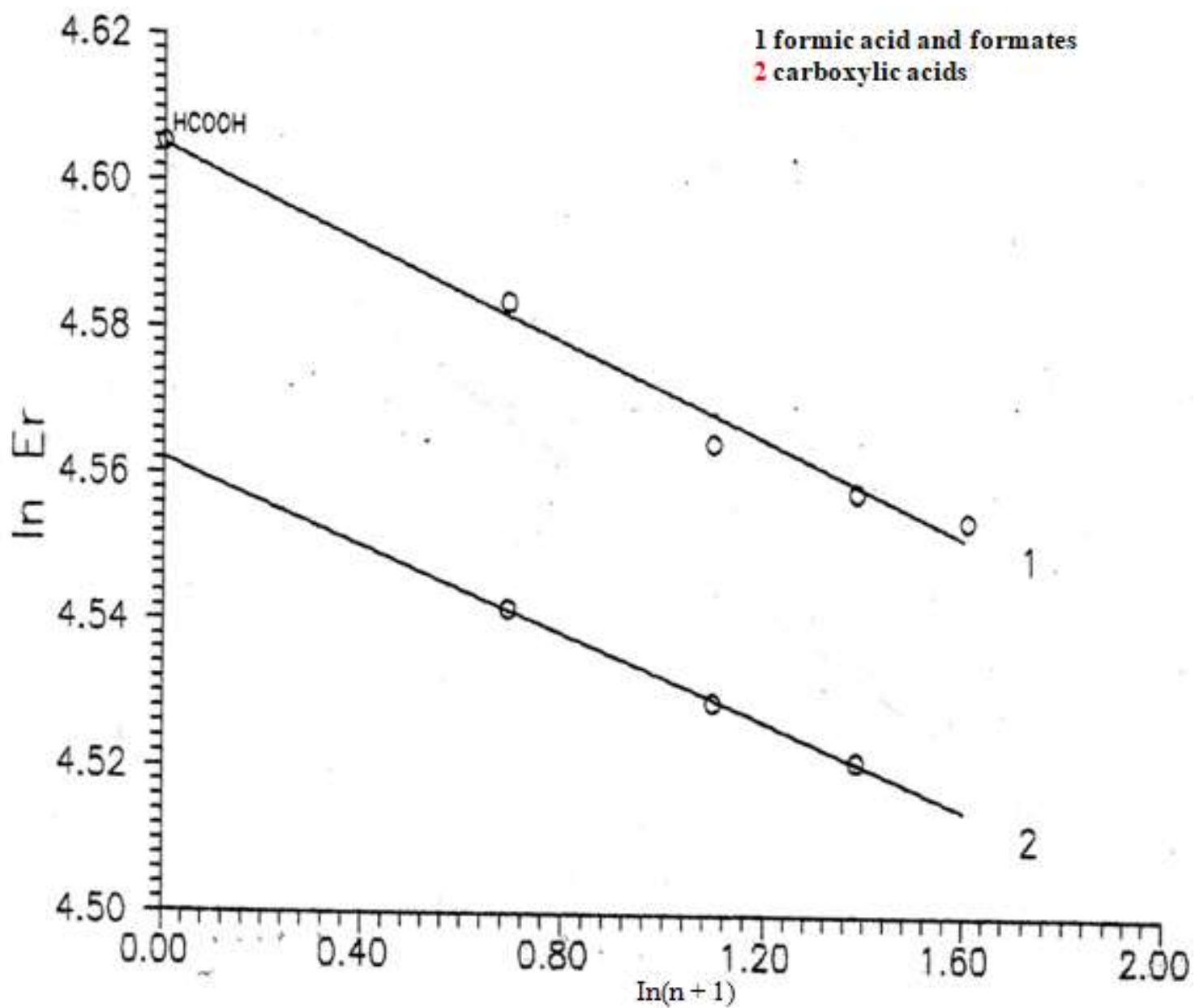

Figure 5: The logarithmic functions with best coefficients of correlation of relative ionization energies (Er) and no. of carbon atoms (n) for formic acid, formates and carboxylic acids. Er-values were referred to the ionization energy of $\mathrm{HCOOH}$ taken as $11.05 \mathrm{eV}(11)$.

Volume 6 Issue 12, December 2017

www.ijsr.net

Licensed Under Creative Commons Attribution CC BY 


\section{International Journal of Science and Research (IJSR)

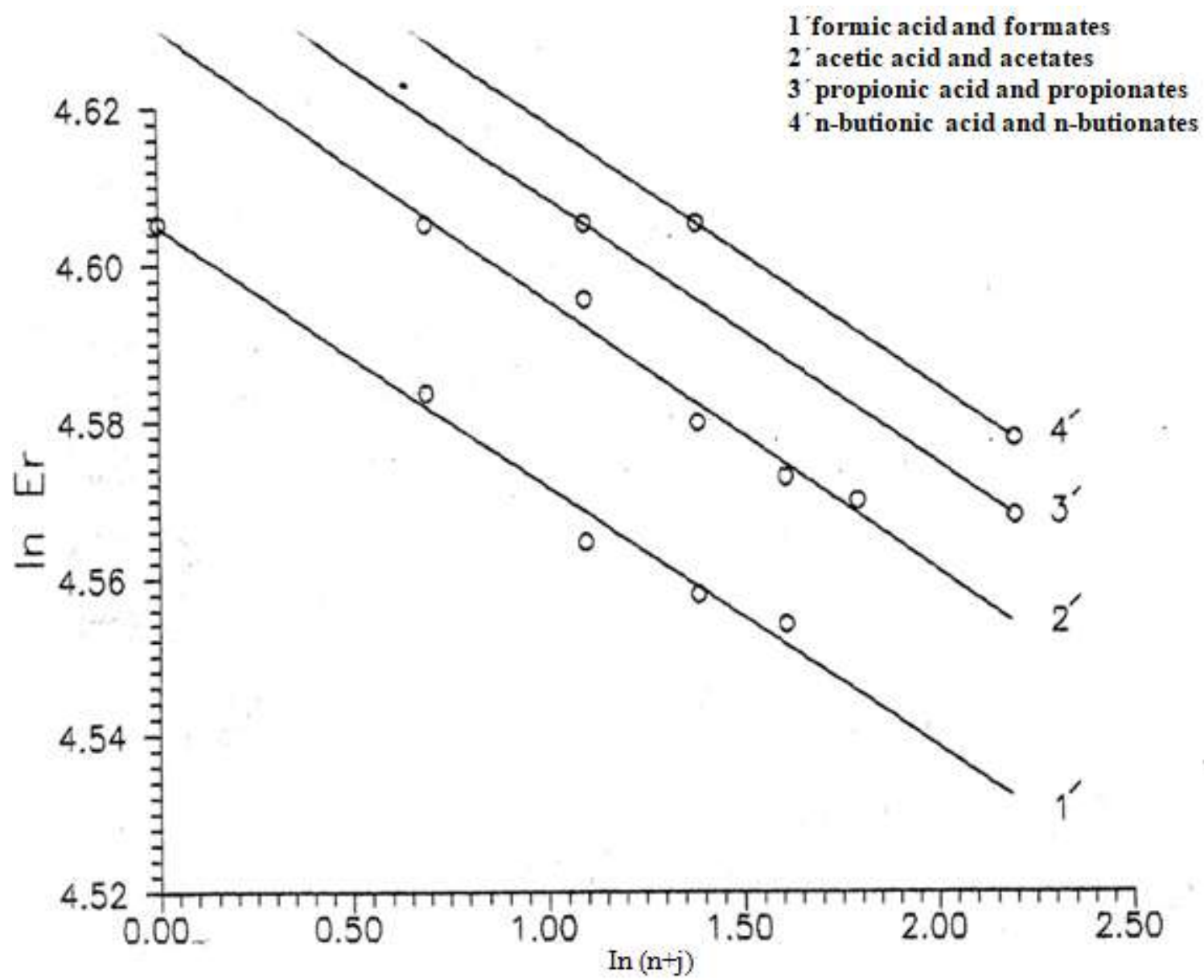

Figure 6: The logarithmic functions with best coefficients of correlation of relative ionization energies (Er) and no. of carbon atoms (n) for formates, acetates, propionates and n-butionates.

Er-values were referred to the parent molecule for each set, $\mathrm{Ei}-\mathrm{HCOOH}=11.05 \mathrm{eV}, \mathrm{Ei}-\mathrm{CH}_{3} \mathrm{COOH}=10.37 \mathrm{eV}$, $\mathrm{Ei}-\mathrm{C}_{2} \mathrm{H}_{5} \mathrm{COOH}=10.24 \mathrm{eV}, \mathrm{Ei}^{-} \mathrm{C}_{3} \mathrm{H}_{7} \mathrm{COOH}=10.16 \mathrm{eV}(11)$.

\section{Summary}

1) There was remarkable arrangement in the behavior of different alkyl derivatives when ionizing energies were simply considered in terms of the number of carbon atoms in alkyl chain.

2) Simple logarithmic functions were found to give linear relationships and intersecting relationships between the corresponding structural chains of compounds

3) These linear correlations and cross-correlations have enabled good estimates of the ionization energies of some alkane derivatives.

\section{References}

[1] G.G. Hell, Trans, Faraday Soc. 1954, 50, 319.

[2] V.M. Baranov and T.K. Rebane, Optices and Spectroscopy (English Translation) 1960, 8, 138.

[3] C.E. Melton and H.W. Joy, Can, J. Chem. 1966, 44, 1455; 1965, 42, 1986 and 2982.

[4] J. Homer and M.S. Mohammadi, J. Chem. Soc. Faraday Trans. 2, 1987, 83, 1975.

[5] C.G. Screttasand M. Micha-Screttas, J. Org. Chem. 1989, 54, 5132.

[6] L.Vriens"Asemi-Empiracal Absolute Cross Excitation Formulafor Calculationof Sectionsfor Ionizationandof Atomsby Electrons" 1965 Physica 31,385-395
[7] Z.A.Saleh , D.K.Taha "Calculation of Ionization energies, electron affinities, hardness's and electro negativites, using many bases set of many methods" International Journal of Scientific \& Engineering Research, Volume 5, Issue 12, December-2014 727 ISSN 2229-5518 IJSER @ 2014 http://www.ijser.org

[8] R. K. Al-Yasari, Z.A.Saleh and D.H. Al-Amiedy "Calculating Structural, Electronics Structures, Electronic Properties and IR Spectra of Pentacene Molecule" International Journal of Advanced Research in Physical Science (IJARPS) Volume 1, Issue 1, May 2014, PP1-9

[9] A.T.M. AL-Thib, B.R.J. Muhyedeen and G.A.W. Derwish, Iraqi J. Chem. Accepted for publication 1992.

[10] J.L. Franklin, J.G. Dillard, H.M. Rosenstock, J.T. Herron, K. Draxl and F.H. Field, Ionization Potentials, Appearance Potentials and Heat of Formation of Gaseous PostiveIons, National Standard Reference Data System, Washington, 1966.

[11]K. Watanabe, T. Nakayama and J. Mottl, J. Quant.Spectrosc. Radiat. Transfer 1962, 2, 369.

[12] Handbook of Chemistry and Physics, CRC Press, Bosa Raton, Florida, $70^{\text {th }}$ edn., 1989-90.

\section{Volume 6 Issue 12, December 2017}

